\title{
Levosimendan in patients with low ejection fraction undergoing cardiac surgery
}

\author{
Ewa M. Kucewicz-Czech¹, Tomasz Maciejewski², Barbara Budziarz², Tadeusz Kołodziej², Kazimierz Kiermasz², \\ Leszek Machej ${ }^{2}$
}

${ }^{1}$ Chair and Clinic of Anesthesiology and Intensive Care, Medical University of Silesia, Katowice, Poland

${ }^{2}$ Department of Anesthesiology and Intensive Care with Cardiac Monitoring, Upper Silesian Medical Center, Katowice, Poland

Kardiochirurgia i Torakochirurgia Polska 2018; 15 (1): 31-37

\begin{abstract}
Introduction: Significant impairment of left ventricular function causes low cardiac output syndrome in the immediate postoperative period in $3-14 \%$ of patients undergoing surgery, increasing the mortality 15 -fold.

Aim: To assess the use of levosimendan in patients undergoing cardiac surgery in 2016.

Material and methods: The analysis included 14 patients: 3 (21.4\%) women and 11 (78.6\%) men aged $65.4 \pm 11.8$ years. The mean value of left ventricular ejection fraction amounted to $20 \pm 6.25 \%$. In 11 patients, levosimendan infusion was started immediately after the induction of anesthesia. Three patients received the agent during the early postoperative period due to low cardiac output syndrome refractory to conventional therapy. The dosage was modified within the range of $0.05-0.2 \mu \mathrm{g} / \mathrm{kg} / \mathrm{min}$. On the day of the surgery, all patients received continuous infusion of adrenaline and levonor.

Results: The cardiac index amounted to $2.8 \pm 0.71 \mathrm{l} / \mathrm{m}^{2}$ after several hours of infusion and $2.9 \pm 0.1 \mathrm{l} / \mathrm{m}^{2}$ the next morning. The first examination showed that the mean systemic vascular resistance was $1010 \mathrm{dyn} / \mathrm{s}^{-5}$ and the second: $940 \pm 100 \mathrm{dyn} / \mathrm{s}^{-5}$; mixed venous blood saturation amounted to $66 \pm 7.5 \%$ and 65.5 $\pm 8 \%$, respectively. Respectively, the mean concentration of lactates was $2.0 \pm 0.96 \mathrm{mmol} / \mathrm{l}$ and $1.8 \pm 0.24 \mathrm{mmol} / \mathrm{l}$. Mechanical lung ventilation lasting more than 48 hours was required in $50 \%$ of the patients. Two patients with chronic kidney disease required bedside renal replacement therapy before the procedure. Two (14.3\%) patients died. Nine (64.3\%) patients were discharged home, and three were transferred to cardiac wards. Conclusions: Levosimendan therapy proved safe in the study group. The nature of the study and the small sample size preclude the formulation of detailed conclusions.
\end{abstract}

Key words: levosimendan, cardiac surgery, low cardiac output syndrome.

\section{Streszczenie}

Wstęp: Istotne upośledzenie funkcji lewej komory serca jest przyczyną zespołu małego rzutu w bezpośrednim okresie pooperacyjnym. Dotyczy 3-14\% operowanych chorych, śmiertelność w takich przypadkach wzrasta 15-krotnie.

Cel: Oceniono zastosowanie lewosimendanu u chorych poddawanych zabiegom kardiochirurgicznym w 2016 roku.

Materiał i metody: Analizą objęto 14 pacjentów, w tym 3 (21,4\%) kobiety i 11 (78,6\%) mężczyzn w wieku 65,4 $\pm 11,8$ roku. Średnia wartość frakcji wyrzutowej lewej komory serca wynosiła $20 \pm 6,25 \%$. U 11 pacjentów infuzję lewosimendanu rozpoczęto bezpośrednio po indukcji znieczulenia. Trzech chorych otrzymato lek we wczesnym okresie pooperacyjnym z powodu zespołu małego rzutu, niepoddającego się konwencjonalnej terapii. Dawkę lewosimendanu modyfikowano w zakresie wartości $0,05-0,2 \mu \mathrm{g} / \mathrm{kg} / \mathrm{min}$. W pierwszej dobie operacji wszyscy chorzy otrzymywali wlew ciągły adrenaliny i lewonoru.

Wyniki: Indeks sercowy w kilka godzin po rozpoczęciu infuzji wynosit 2,8 $\pm 0,71 \mathrm{l} / \mathrm{m}^{2}$, w kolejnej dobie rano 2,9 $\pm 0,1 \mathrm{l} / \mathrm{m}^{2}$. Naczyniowe opory systemowe w pierwszym badaniu wyniosty średnio $1010 \mathrm{dyn} / \mathrm{s}^{-5}$, a w kolejnym badaniu $940 \pm 100 \mathrm{dyn} / \mathrm{s}^{-5}$. Saturacja mieszanej krwi żylnej w pierwszym punkcie czasowym wyniosła $66 \pm 7,5 \%$, a w kolejnym 65,5 $\pm 8 \%$. Średnie stężenie mleczanów wynosiło w pierwszym punkcie czasowym 2,0 $\pm 0,96$ $\mathrm{mmol} / \mathrm{l}$, a w kolejnym 1,8 $\pm 0,24 \mathrm{mmol} / \mathrm{l}$. Połowa pacjentów wymagała wentylacji mechanicznej płuc powyżej 48 godzin. Dwóch chorych z przewlekłą niewydolnością nerek przed operacją wymagało przyłóżkowej terapii nerkozastępczej. Dwóch $(14,3 \%)$ chorych zmarło. Dziewięciu $(64,3 \%)$ chorych wypisano do domu, 3 pacjentów przekazano na oddziały kardiologii.

Wnioski: W badanej grupie terapia lewosimendanem okazała się bezpieczna. Charakter badania i mała liczba pacjentów nie pozwala na formułowanie szczegółowych wniosków.

Słowa kluczowe: lewosimendan, kardiochirurgia, zespół matego rzutu serca.

Address for correspondence: Prof. Ewa M. Kucewicz-Czech MD, PhD, Chair and Clinic of Anesthesiology and Intensive Care, Medical University of Silesia, 15 Medyków St, 40-752 Katowice, Poland, phone: +48 604451 880, e-mail: j.ciesla@sccs.pl

Received: 20.11.2017, accepted: 5.12.2017. 


\section{Introduction}

Cardiac surgery procedures are an established method of treating cardiac diseases. The popularity of this form of therapy is reflected by the number of procedures performed each year; in Europe and the USA, this number amounts to over a million [1]. Patients referred for cardiac surgery are increasingly older and burdened with numerous comorbidities. Just a few years ago, such patients were being disqualified from surgical treatment. Today, older patients with comorbidities can benefit from surgical heart repair; nevertheless the risk of postoperative complications and mortality in such patients is higher.

Significant impairment of left ventricular function is one of the causes of low cardiac output syndrome during the immediate postoperative period. This complication occurs in $3-14 \%$ of patients undergoing surgery; the mortality in this group increases 15 -fold. The patients require extra doses of agents to improve cardiac function, which generates a dramatic increase in side effects, vasoconstriction and ischemia, tachycardia and increased myocardial demand of oxygen, arrhythmias, limited coronary perfusion, anaerobic cellular metabolism, increased lactate concentration and maximal oxygen extraction with low venous saturation, resulting in multiple organ dysfunction syndrome. Clinical studies (single center studies, meta-analyses) suggest that the use of catecholamines, especially those acting through $\beta$-receptors, may be associated with worse long-term outcomes [2]. The inodilator milrinon, used in low cardiac output syndrome, has many side effects; some authors also point out that it may increase the risk of death in patients undergoing therapy with phosphodiesterase III inhibitors [3]. Another therapeutic option for postoperative heart failure is to provide mechanical support with intraaortic counterpulsation. However, clinical practice often shows that the increase in cardiac output by approximately $0.5 \mathrm{l} / \mathrm{min}$ that can be achieved with an intra-aortic balloon proves insufficient. Other methods of mechanical support (like post-cardiotomy AV-ECMO) are usually contraindicated in patients older than 70 and are burdened with 50\% mortality. Transesophageal echo results indicate that right ventricular dysfunction occurs in $40 \%$ of patients in whom symptoms of cardiogenic shock develop after the procedure [4].

The optimal management consists in preventing postoperative low cardiac output syndrome. This may perhaps be achieved with levosimendan as its pharmacokinetic characteristics offer some hope for success in this regard. The drug has been classified as an "inoprotector".

Levosimendan induces calcium to bond with troponin C, sensitizing myofilaments to calcium. Its mechanism of action also includes the activation of ATP-dependent potassium channels, which results in improved myocardial contractility, vasodilation, and cardioprotection. Levosimendan does not increase mycoardial demand for oxygen. Its combined inotropic and vasodilatory effects increase the strength of contraction, at the same time reducing both preload and afterload in both ventricles. Its cardiopro- tective action limits mitochondrial pathway apoptosis [5]. The metabolism of levosimendan is complex. After many biochemical reactions, a part of its dose forms an active form, QR-1896, with properties similar to those of the original form, but with better clinical potential. Its maximum concentration in patients with heart failure is observed 2-4 days after the start of a 24-hour infusion. In patients after cardiac surgery involving extracorporeal circulation, the formation of this active metabolite is delayed, and its maximum concentration is observed 5-6 days after the start of the infusion. The drug's action persists for 1-1.3 weeks [6]. The beneficial effect of levosimendan could potentially be compromised by the drug's vasodilatory properties, which result in hypotension and an increased demand for vasopressors [7]. Abandoning the use of a loading dose and controlling the dosage of the continuous infusion largely reduced the problem of hypotension. Levosimendan may increase bleeding and the risk of cardiac arrhythmias.

Data from small randomized studies and meta-analyses indicate that levosimendan is effective in preventing and treating low cardiac output syndrome. The results of large randomized studies published in 2016 and 2017 offer less optimism $[1,8,9]$. The current debate on the effectiveness of levosimendan focuses on the time of its administration, which may prove to be a key element of the therapy. Beyond all doubt, all researchers unanimously report that the agent is safe.

\section{Material and methods}

This retrospective analysis included 14 patients who received levosimendan in 2016 and were postoperatively hospitalized at the Department of Intensive Care with Cardiac Monitoring of the Upper Silesian Center of Cardiology in Katowice. Due to its retrospective character, the study did not require the approval of the local Bioethics Committee. The analysis included 3 (21.4\%) women and 11 (78.6\%) men aged $65.4 \pm 11.8$ years. Five patients underwent elective surgery, the others were operated on urgently. Thirteen patients had impaired cardiac function before the surgery (cardiomyopathy). One female patient was operated on urgently after a percutaneous coronary intervention; prior to the incident, her cardiac function was normal. The average value of left ventricular ejection fraction in the analyzed group amounted to $20 \pm 6.25 \%$. In $50 \%$ of the patients, the primary cardiac rhythm was atrial fibrillation. The average value of Euroscore II was $5.4 \pm 1.68$ points (Table I). Three patients underwent coronary artery bypass grafting (CABG); in 7 patients, CABG was combined with valve repair or replacement; valve procedures were performed in further 3 patients; 1 patient underwent decompression of cardiac tamponade and repair of the bleeding site. One patient was operated on without extracorporeal circulation (iatrogenic tamponade after the removal of endocavitary electrodes). The average time of extracorporeal circulation was $98.4 \pm 53.95$ minutes, the average aortic cross-clamping time was $58.4 \pm 31.35$ minutes (Table II). Five patients had concomitant chronic kidney disease. 
Table I. Characteristics of patients receiving levosimendan

\begin{tabular}{|c|c|c|c|c|c|c|c|}
\hline Patient & Age [years] & Gender & Comorbidity & Mode of admission & Chronic AF & EURO score & $\mathrm{EF}(\%)$ \\
\hline 1 & 72 & $\mathrm{~F}$ & Severe pulmonary hypertension & Elective & Yes & 8.5 & 20 \\
\hline 2 & 48 & M & Cardiomyopathy & Urgent & & 25.6 & 14 \\
\hline 3 & 77 & M & Cardiomyopathy & Elective & & 5.33 & 25 \\
\hline 4 & 64 & $\mathrm{~F}$ & Diastolic failure & Urgent & Yes & 3.78 & 40 \\
\hline 5 & 66 & M & Cardiomyopathy & Elective & Yes & 2.52 & 20 \\
\hline 6 & 81 & M & Cardiomyopathy & Urgent & Yes & 42.94 & 15 \\
\hline 7 & 50 & M & STEMI & Urgent & & 4.99 & 20 \\
\hline 8 & 56 & M & Cardiomyopathy & Urgent & Yes & 5.25 & 30 \\
\hline 9 & 70 & M & Cardiomyopathy & Urgent & Yes & 5.25 & 20 \\
\hline 10 & 76 & $\mathrm{~F}$ & Unsuccessful PCI RCA & Urgent & & 8.13 & 50 \\
\hline 11 & 68 & M & Diastolic failure & Elective & Yes & 10.27 & 37 \\
\hline 12 & 44 & M & Cardiomyopathy & Elective & & 4.14 & 20 \\
\hline 13 & 78 & M & Cardiomyopathy & Urgent & & 6 & 15 \\
\hline 14 & 65 & M & Cardiomyopathy & Urgent & & 5.49 & 15 \\
\hline Mean \pm SD & $65.4 \pm 11.8$ & $\begin{aligned} F: n & =3 ; 21.4 \% \\
M: n & =11 ; 78.6 \%\end{aligned}$ & $x x x$ & $x x x$ & $n=7(50 \%)$ & $5.41 \pm 1.68^{*}$ & $20 \pm 6.25^{\star}$ \\
\hline
\end{tabular}

*Median \pm quartile deviation, $\mathrm{F}$ - female, $\mathrm{M}$ - male, STEMI - ST-elevation myocardial infarction, $\mathrm{PCl}$ - prcutaneous coronary intervention, RCA - right coronary artery, AF - atrial fibrillation, EURO score - modified score for the risk of death in cardiac surgery patients, EF - left ventricular ejection fraction.

Table II. Types of procedures performed in the study group

\begin{tabular}{lcccc} 
Patient & Types of procedures & Group & $\begin{array}{c}\text { Extracorporeal circulation time } \\
{[\text { in] }}\end{array}$ & $\begin{array}{c}\text { Cross-clamping time } \\
\text { [min] }\end{array}$ \\
\hline 1 & MVpl, TVpl & Valve surgery & 34 & 15 \\
\hline 2 & Tamponade after pacemaker implantation & Tamponade & N/A & n/a \\
\hline 3 & CABG & Bypass grafting & 186 & 60 \\
\hline 4 & TVpl, MVpl, ablation & Valve surgery & 128 & 101 \\
\hline 5 & AVR, ablation & Valve surgery & 92 & 72 \\
\hline 6 & AVR, CABG & Complex surgery & 76 \\
\hline 7 & MVpl, CABG & Complex surgery & 96 & 74 \\
\hline 8 & Pericardiectomy, CABG & Complex surgery & 30 \\
\hline 9 & CABG, MVpl & Complex surgery & 101 & 104 \\
\hline 10 & CABG & Bypass grafting & 50 & 15 \\
\hline 11 & AAA, CABG & Complex surgery & 37 & 89 \\
\hline 12 & CABG, MVpl & Complex surgery & 113 & 78 \\
\hline 13 & CABG & Bypass grafting & 125 & 15 \\
\hline 14 & CABG, MVpl & Complex surgery & 35 & 73 \\
\hline & & Mean \pm SD & 96 & $58.4 \pm 31.35$ \\
\hline
\end{tabular}

$\mathrm{MVpl}$ - mitral valvuloplasty, TVpl - tricuspid valvuloplasty, CABG - coronary artery bypass grafting, AVR - aortic valve replacement, AAA - ascending aorta replacement due to an aneurysm, N/A - not applicable.

Levosimendan, Simdax (Orion) was administered via continuous intravenous infusion. A 12.5 -mg ampule was dissolved in $250 \mathrm{ml}$; the infusion was planned for 24 hours, starting with a rate of $10 \mathrm{ml} / \mathrm{h}$. The rate of infusion was adjusted to the values of arterial blood pressure and systemic vascular resistance. The dosage was modified within the range of $0.05-0.2 \mu \mathrm{g} / \mathrm{kg} / \mathrm{min}$. In 11 patients, levosimendan infusion was started immediately after the induction of anesthesia. Three patients received the agent during the early postoperative period due to low cardiac output syndrome refractory to conventional therapy. In all patients except for the patient with tamponade, cardiac function received additional mechanical support with intra-aortic counterpulsation. The function of the circulatory system was monitored using a Swan-Ganz catheter. Due to technical considerations, one of the patients was not monitored for cardiac output and mixed venous blood saturation. Replenishment of the vascular bed and the dosage of catecholamines were adjusted to the hemodynamic profile in accordance with the principles of goal-directed therapy. The goal was to maintain the cardiac index $(\mathrm{Cl})$ at $\geq 2.4 \mathrm{l} / \mathrm{min} / \mathrm{m}^{2}$; mixed venous blood saturation at $>60 \%$; mean systemic pressure 
Table III. Hemodynamic profile, oxygen balance, and pharmacological and mechanical support for cardiac function on the day of the surgery and the first postoperative day

\begin{tabular}{|c|c|c|c|c|c|c|c|c|c|c|c|}
\hline Patient & $\mathrm{Cl}_{1}$ & $\mathrm{SVR}_{1}$ & $\operatorname{satV}_{1}$ & IABP & Lactates $_{1}$ & Adrenaline $_{1}$ & Leonor $_{1}$ & $\mathrm{Cl}_{1 \mathrm{a}}$ & $\mathrm{SVR}_{1 \mathrm{a}}$ & SatV $_{1 a}$ & Lactates $_{1 \mathrm{a}}$ \\
\hline 1 & 1.6 & 2380 & 72 & Yes & 2 & $\leq 0.1$ & $\leq 0.1$ & 2.8 & 1400 & 69 & 2.1 \\
\hline 2 & 2.5 & 1335 & 60 & No & 1.5 & $>0.1$ & $\leq 0.1$ & 3 & 840 & 69 & 1.7 \\
\hline 3 & 3 & 1140 & 58 & Yes & 3.6 & $\leq 0.1$ & $\leq 0.1$ & 2.9 & 1100 & 58 & 1.7 \\
\hline 4 & 2.3 & 823 & 65 & Yes & 1.3 & $\leq 0.1$ & $\leq 0.1$ & 2.6 & 826 & 58 & 1.7 \\
\hline 5 & 4 & 830 & 78 & Yes & 2.4 & $\leq 0.1$ & $\leq 0.1$ & 4 & 900 & 74 & 1.7 \\
\hline 6 & 2.8 & 1600 & 73 & Yes & 1.7 & $\leq 0.1$ & $\leq 0.1$ & 3.6 & 1000 & 76 & 1.8 \\
\hline 7 & 3.9 & 1100 & 57 & Yes & 1.6 & $\leq 0.1$ & $\leq 0.1$ & 3.5 & 910 & 53 & 1.8 \\
\hline 8 & $n / a$ & $\mathrm{n} / \mathrm{a}$ & $n / a$ & Yes & 1.9 & $\leq 0.1$ & $>0.1$ & N/A & $n / a$ & $n / a$ & 2.2 \\
\hline 9 & 2.35 & 970 & 57 & Yes & 3.4 & $\leq 0.1$ & $\leq 0.1$ & 2.9 & 940 & 58 & 1.9 \\
\hline 10 & 2.6 & 850 & 67 & Yes & 5 & $\leq 0.1$ & $\leq 0.1$ & 2.9 & 1100 & 65 & 3.1 \\
\hline 11 & 2.7 & 1050 & 56 & Yes & 1.8 & $\leq 0.1$ & $>0.1$ & 2.8 & 1050 & 63 & 1.6 \\
\hline 12 & 2.4 & 900 & 64 & Yes & 5.2 & $>0.1$ & $\leq 0.1$ & 3 & 1000 & 68 & 3.4 \\
\hline 13 & 2.3 & 1100 & 75 & Yes & 1.3 & $\leq 0.1$ & $\leq 0.1$ & 2.5 & 850 & 80 & 2.3 \\
\hline 14 & 3.8 & 950 & 76 & Yes & 7.5 & $>0.1$ & $>0.1$ & 3 & 750 & 61 & 1.5 \\
\hline $\begin{array}{l}\text { Mean } \pm \\
\text { SD }\end{array}$ & $\begin{array}{c}2.8 \\
\pm 0.71\end{array}$ & $\begin{array}{c}1010 \\
\pm 120^{*}\end{array}$ & $\begin{array}{c}66 \\
\pm 7.50^{*}\end{array}$ & $x x x$ & $\begin{array}{c}2.0 \\
\pm 0.96^{*}\end{array}$ & $x x x$ & $x x x$ & $2.9 \pm 0.10^{*}$ & $940 \pm 100^{*}$ & $\begin{array}{r}65.5 \\
\pm 8.04\end{array}$ & $1.8 \pm 0.24^{*}$ \\
\hline
\end{tabular}

${ }^{*}$ Median \pm quartile deviation. $\mathrm{Cl}_{1}$ - cardiac index in $\mathrm{l} / \mathrm{m}^{2}$ measured on the day of the surgery after hemodynamic stabilization, $\mathrm{SVR}_{1}-$ systemic vascular resistance in $\mathrm{dyn} / \mathrm{s}^{-5}$ measured on the day of the surgery after hemodynamic stabilization, sat $\mathrm{V}_{1}$ - mixed venous blood saturation measured on the day of the surgery after hemodynamic stabilization, IABP - intra-aortic balloon pump, lactates ${ }_{1}$ lactate concentration in mmol/l measured on the day of the surgery after hemodynamic stabilization, adrenaline ${ }_{1}$ - dose of adrenaline in $\mu \mathrm{g} / \mathrm{kg} / \mathrm{min}$ administered on the day of the surgery after hemodynamic stabilization, levonor ${ }_{1}$ - dose in $\mu \mathrm{g} / \mathrm{kg} / \mathrm{min}$ administered on the day of the surgery after hemodynamic stabilization; $\mathrm{Cl}_{1 \mathrm{a}}, \mathrm{SVR}_{1 \mathrm{a}}$, sat $\mathrm{V}_{1 \mathrm{a}}$, lactates $\mathrm{s}_{1 \mathrm{a}}-$ parameters assessed in the morning of the day following the surgery; N/A - not available.

at $>65 \mathrm{~mm} \mathrm{Hg}$; and lactate concentration at $\leq 2 \mathrm{mmol} / \mathrm{l}$. Hemodynamic measurements were taken 4 times per day. Cardiac output measurements were not compared to values from before the administration of levosimendan as 11 patients received the drug preoperatively due to significantly reduced ejection fraction, regardless of the postoperative development of low cardiac output syndrome. The patients received continuous infusion of noradrenaline and/or adrenaline dosed in accordance with the principles of goal-directed therapy.

\section{Statistical analysis}

Statistical analysis was conducted using Microsoft Office Excel 2010 and Statistica 12.0. ${ }^{\circledR}$ The Shapiro-Wilk W test was used to determine the dataset. Data with normal distribution were presented as arithmetic mean \pm standard deviation; data with non-normal distribution were presented as median \pm quartile deviation. To compare percentages, a test for the significance of the difference between two structure indices was used. For difference tests, statistical significance was set at $p<0.05$.

\section{Results}

Hemodynamic profiles and oxygen balance were analyzed based on mixed venous blood saturation a few hours after the start of the levosimendan infusion and on the next morning. On the day of the surgery, all patients received continuous infusion of adrenaline and noradrenaline. Three patients required adrenaline and/or noradrena- line in doses exceeding $0.1 \mu \mathrm{g} / \mathrm{kg} / \mathrm{min}$. One patient received both amines in a dose exceeding $0.1 \mu \mathrm{g} / \mathrm{kg} / \mathrm{min}$. The cardiac index amounted to $2.8 \pm 0.71 \mathrm{l} / \mathrm{m}^{2}$ after several hours of infusion and $2.9 \pm 0.1 \mathrm{l} / \mathrm{m}^{2}$ the next morning. The mean systemic vascular resistance in the first examination was 1010 dyn $/ \mathrm{s}^{-5}$ and in the second examination: $940 \pm 100 \mathrm{dyn} / \mathrm{s}^{-5}$; respectively, mixed venous blood saturation amounted to $66 \pm 7.5 \%$ and $65.5 \pm 8 \%$. Respectively, the mean concentration of lactates was $2.0 \pm 0.96 \mathrm{mmol} / \mathrm{l}$ and $1.8 \pm 0.24 \mathrm{mmol} / \mathrm{l}$ (Table III). Mechanical lung ventilation lasting more than 48 hours was required in $50 \%$ of the patients.

Atrial fibrillation occurred in 5 patients with sinus rhythm. Two patients with chronic kidney disease required bedside renal replacement therapy before the procedure. Two (14.3\%) patients died. Nine (64.3\%) patients were discharged home, and three were transferred to cardiac wards (Table IV).

\section{Discussion}

The ambivalent reports on the use of levosimendan to improve the results of heart failure treatment prompted researchers to conduct large randomized trials on the use of this agent in cardiac surgery patients. Considering the agent's pharmacokinetic properties, the research hypothesis was that it would reduce mortality after cardiac surgery in patients with concomitant heart failure or heart failure developing in the perioperative period. The results of the CHEETAH study were published in print in April 2017 [8]. Its participants received the agent at different times of 
the perioperative period, in doses that were significantly smaller than the recommended dose. The duration of infusion was increased to 48 hours. Only $4.3 \%$ of the patients received levosimendan preoperatively; these were patients with low initial left ventricular function. The remaining patients were included in the study at various stages of treatment due to the necessity of mechanical cardiac support with intra-aortic counterpulsation. The study's methodology did not include the measurement of cardiac output. The analysis did not confirm the agent's influence on reducing 30-day mortality in patients after cardiac surgery procedures. However, in view of the most recent guidelines, it seems that high-risk patients, which include patients with significantly impaired cardiac function (EF $\leq 25 \%$ ), require therapy based on hemodynamic monitoring with cardiac output measurements. Such management enables optimal vascular bed filling and individual selection of the types and doses of medications increasing contractility and correct vascular resistances. Scientists from the Vanderbilt University conducted a study that encompassed over 6,000 patients undergoing cardiac surgery procedures. The study demonstrated that hemodynamic monitoring using a Swan-Ganz catheter reduces the incidence of heart failure, lung failure, and bleeding; it has no bearing on mortality, length of hospitalization, or unplanned readmissions; and it increases the incidence of bacteremia and urinary tract infections [10].

In our material, 3 patients received levosimendan postoperatively. One female patient suffered from concomitant carcinoid syndrome. She underwent mitral and tricuspid valvuloplasty. Due to the carcinoid syndrome, she did not receive catecholamines after the surgery. On the $2^{\text {nd }}$ postoperative day, a decision was made to introduce levosimendan therapy due to symptoms of low cardiac output syndrome. The patient died on the $14^{\text {th }}$ postoperative day, having presented signs of multiple organ dysfunction syndrome and infectious complications (pneumonitis). Renal replacement therapy was used during the treatment, as the patient was burdened with chronic kidney disease. Another patient who received levosimendan postoperatively was a woman with good left ventricular function who was operated on urgently due to unstable ischemic heart disease. Intraoperatively, after the pericardial sac was opened, an extensive infarct was observed in the wall of the right ventricle and the right atrium, resulting from unsuccessful right coronary arterioplasty. Low cardiac output syndrome, high lactate concentration, and symptoms of ischemia in the organs of the abdominal cavity were observed during the early postoperative period. Heart failure was initially treated with intra-aortic counterpulsation. Due to persisting heart failure, levosimendan infusion was included in the therapy on the $2^{\text {nd }}$ postoperative day. The patient died due to intestinal ischemia despite undergoing rightsided hemicolectomy and partial resection of the ileum. It appears that the administration of a full dose of heparin before extracorporeal circulation may have caused further expansion of the hematoma and resulted in irreversible
Table IV. Postoperative complications and outcomes of patients receiving levosimendan

\begin{tabular}{|c|c|c|c|c|c|}
\hline Patient & RRT & $\begin{array}{l}\text { Ventilation } \\
>48 \text { hours }\end{array}$ & $\begin{array}{l}\text { Post-op } \\
\text { AF }\end{array}$ & Discharge & Death \\
\hline 1 & & & & Home & \\
\hline 2 & Yes & & Yes & $\begin{array}{l}\text { Another } \\
\text { hospital }\end{array}$ & \\
\hline 3 & & Yes & & Home & \\
\hline 4 & Yes & Yes & & & Yes \\
\hline 5 & & & & Home & \\
\hline 6 & & Yes & & $\begin{array}{l}\text { Another } \\
\text { hospital }\end{array}$ & \\
\hline 7 & & & & Home & \\
\hline 8 & & Yes & & Home & \\
\hline 9 & & Yes & & Home & \\
\hline 10 & & Yes & Yes & & Yes \\
\hline 11 & & & & Home & \\
\hline 12 & & Yes & Yes & Home & \\
\hline 13 & & & Yes & $\begin{array}{l}\text { Another } \\
\text { hospital }\end{array}$ & \\
\hline 14 & & & Yes & Home & \\
\hline N & 2 & 7 & 5 & $\begin{array}{l}\text { Home: } 9 \\
\text { Another } \\
\text { hospital: } 3\end{array}$ & 2 \\
\hline$\%$ & 14.3 & 50 & 35.7 & $\begin{array}{l}64.3 \\
21.4\end{array}$ & 14.3 \\
\hline
\end{tabular}

RRT - renal replacement therapy, AF - atrial fibrillation in patients with preoperative sinus rhythm.

heart failure. The third patient received levosimendan after a sudden cardiac arrest; its most probable etiology was cholesterol embolization. In view of evident signs of heart failure and dramatic left ventricular hypertrophy accompanied by pulmonary edema, agents stimulating $\beta$-receptors were not used, and levosimendan and noradrenaline were administered. Five days prior, the patient underwent a surgical procedure involving the replacement of the ascending aorta and aortic valve and coronary artery bypass grafting (CABG). He remained in the ICU for 27 days; ultimately, he was discharged home.

Another multicenter study, dubbed with the acronym LICORN, was conducted in 13 hospitals in France to assess the efficacy of levosimendan in preventing low cardiac output syndrome after CABG [9]. Levosimendan was administered after anesthesia, dosed at $0.1 \mu \mathrm{g} / \mathrm{kg} / \mathrm{min}$, to patients with left ventricular ejection fraction $\leq 35 \%$. Its efficacy was assessed based on the requirement of positive inotropes after 24 hours from surgery, mechanical support, and renal replacement therapy. Early and 6-month mortality was recorded. The detailed results of the study were published in July 2017. The authors were not able to demonstrate a significant reduction in mortality in the group treated with levosimendan. Notwithstanding, cases of low cardiac output syndrome and requirement of additional agents supporting cardiac function were significantly less frequent. 
Eleven of our patients received levosimendan, dosed at $0.05-0.2 \mu \mathrm{g} / \mathrm{kg} / \mathrm{min}$, after the induction of anesthesia or after the end of extracorporeal circulation. All patients except one (operated on due to iatrogenic heart injury and tamponade after a pacemaker implantation) received mechanical support with intra-aortic counterpulsation. Pharmacotherapy for heart failure was provided on the basis of hemodynamic parameters measured using a Swan-Ganz catheter. Additional monitored parameters influencing the selection of treatment were lactate concentration and mixed venous blood saturation. Hypotension was treated with continuous infusion of norepinephrine, its dose adjusted to the established goal, i.e., maintaining mean arterial blood pressure above $65 \mathrm{~mm} \mathrm{Hg}$. In 5 patients with initially normal sinus rhythm, atrial fibrillation occurred during their stay at the ICU. No anaphylactic reaction to the agent was observed in any of the patients. One patient required resternotomy due to bleeding from the wall of the right atrium. He underwent surgery on the previous day due to constrictive pericarditis and coronary atherosclerosis.

The third multicenter study devoted to the analysis of the outcomes of heart failure treatment with levosimendan in patients after cardiac surgery procedures, with impaired left ventricular function (EF $\leq 35 \%$ ), was LEVO-CTS [1]. Its results did not confirm a reduction in its composite endpoint (mortality, perioperative myocardial infarction, use of mechanical support, necessity of renal replacement therapy) during the early postoperative period in the group of patients receiving levosimendan. In the discussion, the authors suggested that benefits from the therapy may be limited to patients with severe impairment of heart function. They also consider the question of increasing the dose to $>0.2 \mu \mathrm{g} / \mathrm{kg} / \mathrm{min}$ during the initial stage of treatment. The study reported a trend towards a reduction in 90-day mortality (no statistical significance), which was interpreted as a potential possibility of prolonging the life of high-risk patients qualified for cardiac surgery procedures. At the same time, the authors estimated that achieving adequate power for assessing the effect of levosimendan on mortality in a group of such heterogeneity would require the enrollment of 3,000 patients.

The prevalence of heart failure in the population continues to rise, and the number of heart failure patients referred for surgery by cardiologists continues to increase. Optimizing the preoperative condition of patients from this challenging group may have the greatest potential in reducing the risks associated with cardiac surgery [11]. Strategies aiming to achieve this goal include mechanical and pharmacological support of cardiac function. A meta-analysis comparing preoperative treatment with dobutamine, phosphodiesterase inhibitors, levosimendan, and placebo reported a decrease in mortality in the group treated with levosimendan [11]. It should be underscored that positive inotropes should not be used routinely. This type of treatment should be reserved for patients with low cardiac output syndrome, in shock with disturbances of organ perfusion. In such cases, it is worthwhile to adhere to the principles of goal-directed therapy and monitor the hemodynamic parameters using a Swan-Ganz catheter. Optimizing the preoperative clinical condition of patients with severe heart failure requires teamwork and must be treated as a package of actions; single interventions offer little benefit. Levosimendan therapy has been placed on the list of 11 probable non-surgical interventions limiting perioperative mortality. This verdict came in 2016 based on the analysis of literature and the opinions of experts and clinicians (the discussion involved 500 participants) from 61 countries [12].

In our study, levosimendan was added to mechanical support and continuous infusions of adrenaline and noradrenaline. Three patients required more than $0.1 \mu \mathrm{g} / \mathrm{kg} /$ min of adrenaline during the first postoperative day. Only one patient did not receive intra-aortic counterpulsation (iatrogenic pericardial tamponade). Two patients required renal replacement therapy before the procedure due to chronic kidney disease. Mechanical lung ventilation lasting more than 48 hours was required in $50 \%$ of the patients treated with levosimendan. The duration of ICU stay was long, 10 days on average, which to some degree can be attributed to the organizational scheme of the hospital. Nine patients were discharged directly home. Mortality in the discussed group amounted to $14.3 \%$. Mortality associated with postoperative low cardiac output syndrome is estimated at 13-24\% [9].

Levosimendan's protective action in ischemia and reperfusion indicates that it may be justified to use it in advance (preoperatively) in patients with severe impairment of cardiac function undergoing cardiac surgery (preconditioning) [13]. The agent can also be applied in patients requiring pharmacotherapy with catecholamines, in whom mechanical support is planned to be discontinued. A meta-analysis published in 2015 reported shorter ICU stays among patients treated with levosimendan [14]. The demand for an agent with levosimendan's pharmacokinetic properties is enormous, particularly in the context of patients undergoing cardiac surgery procedures. In 2017, the journal "Critical Care" published a metaanalysis of randomized studies involving cardiac surgery patients who were administered levosimendan [15]. The results showed reduced mortality in patients with significant preoperative impairments of systolic function. Additionally, levosimendan therapy is associated with a reduced requirement of renal replacement therapy and shorter ICU stays.

One significant limitation of the present study is the lack of a control group of patients in a similar clinical situation (significantly impaired left ventricular function) who would not receive levosimendan infusions to treat postoperative low cardiac output syndrome.

\section{Conclusions}

In the studied group, therapy with levosimendan proved safe. The patient sample was too small to justify the formulation of more detailed conclusions.

\section{Disclosure}

Authors report no conflict of interest. 


\section{References}

1. Mehta RH, Leimberger JD, van Diepen S, Meza J, Wang A, Jankowich R, Harrison RW, Hay D, Fremes S, Duncan A, Soltesz EG, Luber J, Park S, Argenziano M, Murphy E, Marcel R, Kalavrouziotis D, Nagpal D, Bozinovski J, Toller W, Herlinglake M, Goodman SG, Levy JH, Harrington RA, Anstrom KJ, Alexander JH. Levosimendan in patients wiyh left ventricular dysfunction undergoing cardiac surgery. N Engl J Med 2017; 376: 2032-2042.

2. Landoni G, Biondi-Zoccai G, Greco M, Greco T, Bignami E, Morelli A, Guarracino $\mathrm{F}$, Zangrillo $\mathrm{A}$. Effects of levosimendan on mortality and hospitalization. A meta-analysis of randomized controlled studies. Crit Care Med 2012; 40: 634-646.

3. Majure DT, Greco T, Greco M, Ponschab M, Biondi-Zoccai G, Zangrillo A, Landoni G. Meta-analysis of randomized trials of effect of milrinone on mortality in cardiac surgery: an update. J Cardiothorac Anesth 2013; 27: 220-229.

4. Mebaza A, Pitsis AA, Rudiger A, Toller W, Longrois D, Ricksten SE, Bobek I, De Hert S, Wieseithaler G, Schrime U, von Segesser LK, Sander M, Poldermans D, Ranucci M, Karpati PCJ, Wouters P, Seeberger M, Schmid ER, Weder W, Follath F. Clinical review: practical recommendations on the management of perioperative heart failure in cardiac surgery. Crit Care 2010; 14: 201.

5. Farmakis D, Alvarez J, Ben Gal T, Brito D, Fedele F, Fonseca C, Gordon AC, Gotsman I, Grossini E, Guarracino F, Harjola V, Hellman Y, Heunks L, Ivancan V, Karavidas A, Kivikko M, Lomivorotov V, Longrois D, Masip J, Metra M, Morelli A, Nikolaou M, Papp Z, Parkhomenko A, Poelzl G, Pollesello P, Berg Ravn $\mathrm{H}$, Rex S, Riha H, Ricksten S, Schwinger RHG, Vrtovec B, Yilmaz MB, Zielinska $M$, Parissis J. Levosimendan beyond inotropy and acute heart failure: evidence of pleiotropic effects on the heart and other organs: an expert panel position paper. Int J Cardiol 2016; 222: 303-312.

6. Pisano A, Monti G, Landoni G. Levosimendan: new indications and evidence for reduction in perioperative mortality? Curr Opin Anesthesiol 2016; 29: 454-461.

7. Distelmaier K, Roth C, Schrutka L, Binder C, Steinlechner B, Heinz G, Lang IM, Maurer G, Koinig H, Niessner A, Hulsmann M, Speidl W, Goliasch G. Beneficial effect of levosimendan on survival in patients undergoing extracorporeal membrane oxygenation after cardiovascular surgery. Br J Anaesth 2016 117: 52-58.
8. Landoni G, Lomivorotov VV, Alvaro G, Lobregilo R, Pisano A, Guarracino F, Calabro MG, Grigoryev EV, Likhvatsev VV, Salgado-Filho MF, Bianchi A, Pasyuga VV, Baiocchi M, Pappalardo F, Monaco F, Boboshko VA, Abubakirov MN, Amantea B, Lembo R, Brazzi L, Verniero L, Bertini P, Scandroglio AM, Bove T, Belletti A, Michienzi MG, Shukevich DL, Zabelina TS, Bellomo R, Zangrillo A. Levosimendan for hemodynamic support after cardiac surgery. N Engl J Med 2017; 376: 2021-2031.

9. Caruba T, Hourton D, Sabatier B, Rousseau D, Tibi A, Hoffart-Jourdain C, Souag A, Freitas N, Yjjou M, Almeida C, Gomes N, Aucouturier P, Djadi-Prat J, Menasche P, Chatellier G, Cholley B. Rationale and design of the multicenter randomized trial investigating the effects of levosimendan pretreatment in patients with low ejection fraction $(\leq 40 \%)$ undergoing CABG with cardio pulmonary bypass (LINCORN study) J Cardiothorac Surg 2016; 11: 127-134.

10. Heringlake M. Goal-directed therapy - evidence based or wishful thinking? EACTA Berlin 2017, Plenary Lecture, PL 39.

11. Pichette M, Liszkowski M, Ducharme A. Preoperative optimization of the heart failure patient undergoing cardiac burgery. Can J Cardiol 2017; 33: 72-79.

12. Landoni G, Pisano A, Lomivorotov V, Alvaro G, Hajjar L, Paternoster G, Neto CN, Latronici N, Fominskiy E, Pasin L, Finco G, Lobregilo R, Azzolini ML, Buscaglia G, Castella A, Comis M, Conte A, Conte M, Corradi F, Dal Checco E, De Vuono G, Ganzaroli M, Garofalo E, Gazivoda G, Lembo R, Marianello D, Baiardo Redaelli M, Monaco F, Tarzia V, Mucchetti M, Belletti A, Mura P, Musu M, Pala G, Paltenghi M, Pasyuga V, Piras D, Riefolo C, Roasio A, Ruggeri L, Santini F, Székely A, Verniero L, Vezzani A, Zangrillo A, Bellomo R. Randomized evidence for reduction of perioperative mortality: an updated consensus process. J Cardiothorac Vasc Anesth 2017; 31: 719-730.

13. Greco T, Calabro MG, Covello RD, Greco M, Pasin L, Morelli A, Landoni G, Zangrillo A. A Bayesian network meta-analysis on the effect of inodilatatory agents on mortality. Br J Anaesth 2015; 114: 746-756.

14. Lim JY, Deo SV, Rababah A, Altarabsheh SE, Cho YH, Hang D, McGraw M, Avery EG, Markowitz AH, Park SJ. Levosimendan reduces mortality in adults with left ventricular dysfunction undergoing cardiac surgery: a systemic review and meta-analysis. J Card Surg 2015; 30: 547-554.

15. Chen Q, Zheng R, Lin H, Yu J, Wang H. Effect of levosimendan on prognosis in adult patients undergoing cardiac surgery: a meta-analysis of randomized controlled trials. Critical Care 2017; 21: 253-264. 